\title{
タバコ属植物の細胞遺伝学的研究 $\mathrm{V}^{*}$
}

\section{$N$. suaveolens と他種の交配 3 組合せの $\mathrm{F}_{1}$ の減数分裂}

竹 中 要**

Yô TAKEnAKA: Cytogenetic studies of Nicotiana, V. Reduction divisions in hybrids between $N$. suaveolens and three other spccies, with English summary

1953 年 6 月 8 日受付

本研究の目的㣖 (1) 種間交配による育種的優良形質の発見, (2) 雜種の減数分裂異常を利 用しての優良劣惡両形質の分離，(3) タバコ属の核学的研究方法による系統進化の究明である。

\section{材 料 と 万 法}

研究材料は,「タバコ属植物の細胞遺伝学的研究 I, II」に使用したものを使つた。N.suaveolens $(\mathrm{n}=16)$ は小形の濛州系の種で西る。外形は $N$. alata 系のものに似ている。本種に 同じ嫁州系の $N$. gossei $(\mathrm{n}=18)$ を交配したが，よく結実した。又この相反交雜もよく結実す る。それに反し, alata 系の $N$. alata $(\mathrm{n}=9), N$. longiflora $(\mathrm{n}=10), N$. plumbaginifolia $(\mathrm{n}=10)$ を $N$. suaveolens に交配しけ場合には後二者で辛じて結実を見ただけであつた。こ の三者に N. suaveolens の花粉を交配する相反交雜はすべて不成功であつた。

花粉母:細胞の減数分裂の観察は，すべて鉄醋酸カーミンによるナスリッケ法と，カルノ一氏 液固定後塩酸・醋酸オル七インによる区しつぶし法とによつた。

(1) $N$. suaveolens $\times N$. gossei $の \mathrm{~F}_{1}$

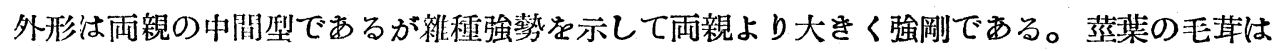
gossei ほど多くないが相当多量に見られる。花筒の毛茸は gossei と同じょうに多い。

減数分裂 太糸期：太䒺期まではちよつと見ると, 正常のものと変りはないが, 上く見る と部分的に 1 重, 2 重, 3 重, 4 重等の染色糸が見られる。殊に太䒺期の頃になると大きな染色糸 の集団の外に離れて少数の小さい集団が見られることがある。

複䒺期：大きな染色分体の集団があり，その外に染色分体の二重となつた小さいものが数 䈏見られることが多い。大きな集団では染色分体の接着の様子を追跡することは困難であるか， あちこちで接着していることは認められる。時に多数の染色分体の接着したものが見られる。

移動期：二価染色体が数䈯見られることがあるが,これはもしろ例外的で三価以上の多価 染色体が多数存在する。五〜七洒のものが見られることもある。

第一中期：二価染色体と多価染色体とが見られる。しかも 1 染色体が 2 籣所以上の点で他 の染色体に接着するものがする。もつとも本雜種では染色体が若干 sticky であり, 又細長いの で種々の機械的接着も考えられる。第一中期核板における一価染色体の数は,

$N$. suaveolens $\times N$. gossei $\mathrm{F}_{1}$ の第一中期一価染色体数

\begin{tabular}{|c|c|c|c|c|c|c|c|c|}
\hline \multicolumn{3}{|c|}{1 価染色体数 } & 0 & 1 & 2 & 3 & 4 & 合 訫 \\
\hline 観 & 察 & 数 & 41 & 46 & 41 & 4 & 2 & 134 \\
\hline
\end{tabular}

* Contributions from the National Institute of Genetics, Japan. No. 49.

** 国立遗伝学研究所 
一価染色体が 3〜4 箇のことは非常に稀れであり,0〜2 筒のことが最も多い。全体数の約 $30 \%$ に達する2籄の一価染色体が gossei からきたものであるどうかは不明であるが, 恐ら く gossei からのものであろう。一価染色体のない場合も約 $30 \%$ 西るが,このときはこれ等 2 簡の染色体は明らかに多価染色体をつくるのに関係している。又一価染色体が 1 䈯のことが約 30\%あるが,この折りにも他の 1 簡は多価染色体をつくるのに関与している。

第一後期：どの母細胞にもほとんど常に染色体橋が見られる。そしてしばしば染色体橫断 が起る。このとき一価染色体には両極の集団から遊離するものがある。

第二分裂：第一分裂で紡鍾体外に遊離した染色体は二分して小さい紡鍾をつくる。又第一 後期で横断された断片にも紡錘体外に圧しだされるものがある。第二中期の核板の染色体数は 15 19 箇であるが, 多くは 16〜18 箇である。これ等は縱裂して第二後期に入つていく。第二 後期でも少数のものに染色体橋を生ずるが，なお外に第一後期の染色体橋の残つているものが ある。この後者の染色体憍は二分するものとしないものとある。こ机等の染色体橋は長く後ま で残つている。

雜種では一般に同一葯內の母細胞に還元分裂の時期的ずれが著るしいが,ことに本雜種で はいちぢるしい。核動期，第一中期を主とするものにおいても，太杀期や第二分裂を示すものが あるし，又第二分裂や四分子期在主とするものにおいても，しばしば太类期，複䒺期，第一分裂 在含む。第一分裂中期を多数もつている䒬では，中期核板の染色体が細長であつて，多数の二価 或は多価染巴体をもつことは上述した通りである。ところが第二分裂から四分子期のものを主 とする葋中に存在する第一分裂中期のものは様子が異つている。その模式的なものは染色体が 親和せす価染色体であり，染色体が短く丸い。すなわち両視からきた染色体が対合しないで 34 簓が一平面上に核板をつくるそして縦裂して両極に向う。もつともこれ等の中にも完全な 34 箇染色体の核板をつくるのから, 時にこく少数の二価, 多価染色体を含む中間型のものも ある。最もいちぢるしいものでは第 1 回に 34 筐が均等分裂をなし，第 2 回目にも均等分裂を なして, 34 箇又はそれに近い染色体をもつ大きな四分子をつくるものがある。

今 1 䒬からの母細胞で第一と第二の分裂を行つたものと, 均等分裂のみ在行いつつあるも のとの頻度を表示する。

N. suaveolens $\times N$. gossei $\mathrm{F}_{1}$ の娍数分裂型と均等分裂型の䪹度

\begin{tabular}{|c|c|c|c|}
\hline 核分裂の型 & 均等分裂型 & 減数分裂型 & 合 計 \\
\hline 観 察 数 & 21 & 93 & 114 \\
\hline
\end{tabular}

四分子期：以上のように不規則な滅数分裂をするから，四分子期の母細胞には 4 よりも少

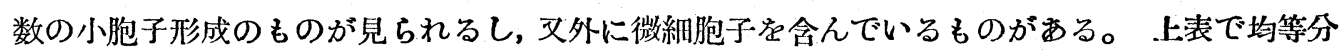
裂型が約 $20 \%$ あつたが，四分子期のものに二分胞子型と三分胞子型とで全母細胞の約 $20 \%$ 見

$N$. suaveolens $\times N$. gossei $\mathrm{F}_{1}$ の四分子期の小胞子数

\begin{tabular}{|c|c|cc|cc|ccc|c|}
\hline $\begin{array}{c}\text { 小胞子 } \\
\text { 微細胞子数 }\end{array}$ & I & II & $\mathrm{II}_{+1}{ }^{*}$ & III & $\mathrm{III}_{+1}$ & $\mathrm{IV}$ & $\mathrm{IV}+1$ & $\mathrm{IV}+2$ & 合計 \\
\hline 観 察 数 & 1 & 11 & 12 & 8 & 1 & 97 & 34 & 3 & 167 \\
\hline
\end{tabular}

*アラビヤ数字は微細胞子数を示す。 
られてたのは,上の関係とよく一致する。

(2) N. suaveolens $\times N$. plumbaginifolia $の \mathrm{~F}_{1}$

外形的に両親がやや似た植物であるから， $\mathrm{F}_{1}$ が何れの親により多く似ているかということ は.困難である。一般的には両親の中間型を示し, 両親よりも丈夫で花数も多く開花期も永く雜 種強勢を示す。

減数分裂 複糸期：太糸期までは大略的に見て正常のものと大した区別はないが，何れの 時期でも染色糸は 1 本すつで本行した複性のものは殆んど見られない。複糸期に括いても本行 したり繩状にねじれるものはない。ただ時に染色分体の集団からはづれた 2〜3 の染色分体が 見られることがある。

移動期： suaveolens からの 16 と plumbaginifolia からの 10 からなる 26 染色体は一 価染色体として核內に分散する。しかし二次接合的に 2 の染色体が接近していることはしばし ば認められる。

第一中期：合計 26 の染色体は一価染色体として核內に分散する。移動期の終りの收縮期 から紡鍾䒺の発達にともなつて機会的に紡鍾体內に分散するから，大多数のものは閒もなく両 極に集まるが，少数のものは紡鍾体中央にきて小核板をつくる。その內に少数の二価染色体が 見られる。

$N$. suaveolens $\times N$. plumbaginifolia $\mathrm{F}_{1}$ の第一中期染色体棈成

\begin{tabular}{|c|c|c|c|c|c|c|c|c|}
\hline \multicolumn{3}{|c|}{1 価と 2 価との染色体数 } & \multirow{2}{*}{$\frac{26 I}{49}$} & \multirow{2}{*}{$\frac{1 \mathrm{II}+24 \mathrm{I}}{42}$} & \multirow{2}{*}{$\frac{2 \mathrm{II}+22 \mathrm{I}}{14}$} & \multirow{2}{*}{$\frac{3 I I+20 I}{3}$} & \multirow{2}{*}{$\frac{4 I I+18 I}{1}$} & \multirow{2}{*}{$\begin{array}{c}\text { 合計 } \\
109\end{array}$} \\
\hline 観 & 察 & 数 & & & & & & \\
\hline
\end{tabular}

すをわち多数は一価染色体ばかりか，二価染色体 1 箇のものである。二価染色体 2 箇乃至 4 箇のものが少数存在する。上に述べたように一価染色体が核內に分散し, やがて両極に集まる から，第一中期と後期との区别が困難であるし，その上後期の初めにおいて一価染色体の染色
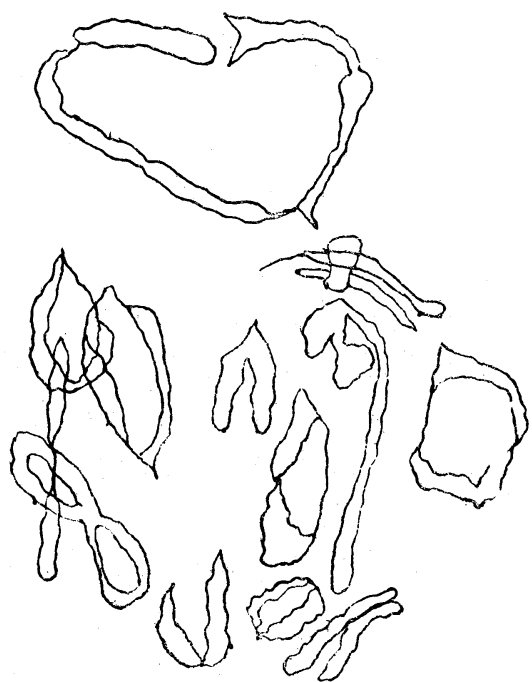

Fig. 1 体橋学二価染色体と見過ることが起りやすいか ら，上表の二価染色体数は実際よりも若干多過ぎ る恐れがある。

第一後期：紡錘体の中央にきた一価染色体は しばしば染色体橋をつくる。又二価染色体も染色

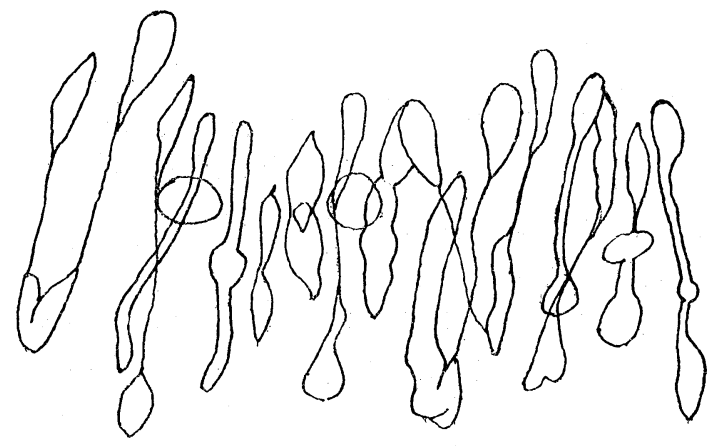

Fig. 2. 


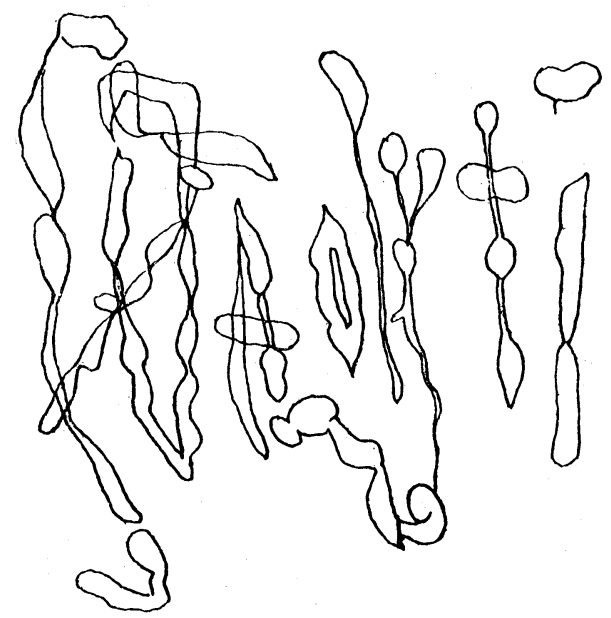

Figs. 1-3: chromosome figures in PMC's of the hybrid $N$. suaveolens $\times N$. gossei. Fig. 1 , diakinesis, showing various chromosome con. jugations. Fig. 2, chromosome figures at IM, showing uni-, bi- and polyvalents. Fig. 3, remarkable end to end conjugations at IM.

Fig. 3.

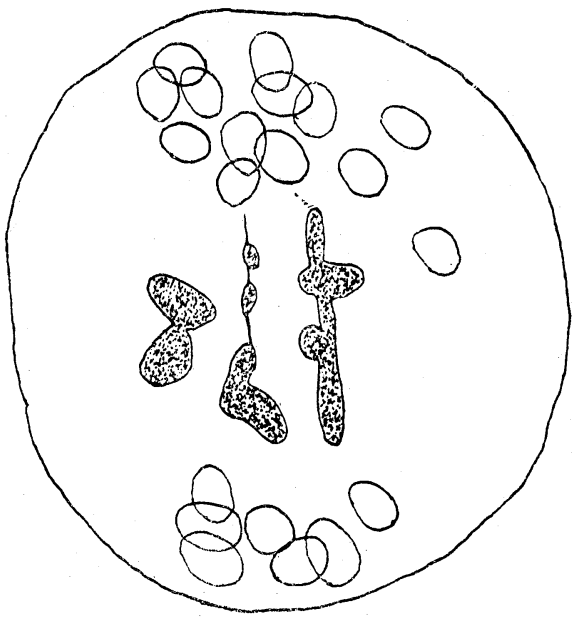

Fig. 4.

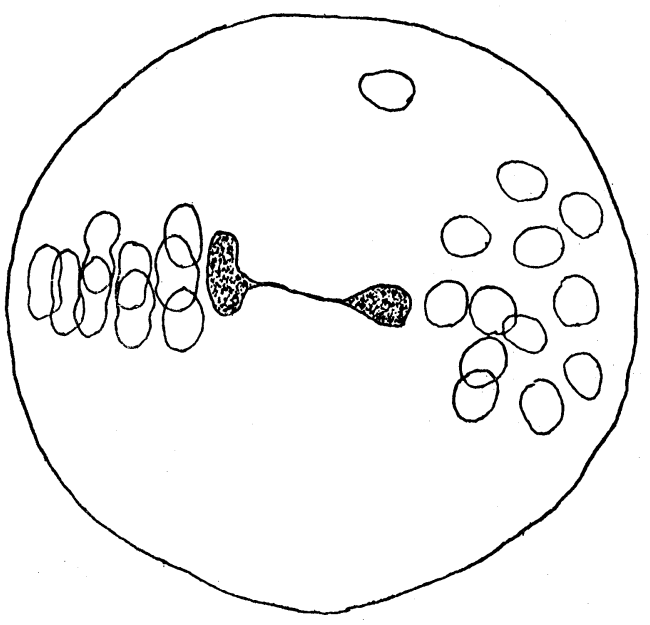

Fig. 5.

Figs. 4-5: chromosome in PMC's of the hybrid $N$. suaveolens $\times N$. plumbaginifolia. Fig. 4, 20 univalents and 3 bivalents at IM. Fig. 5, a chromosome bridge continuing from IA to IIM.

体橋をつくることがある。染色体の少数は両極外で，しかも紡錘体外にでることがある。

第二分裂：中間期には休眠核をつくることなく第二分裂に進行する。核板が構成され染色 体は二分されて，極に行くが，染色体橋がしばしば観察される。このときなお第一分裂の染色体 橋が残つているものがある。第二後期においても第一後期と同様に紡錘体外に放出されたり， 紡鍾体の中央に残る染色体が見られる。

四分子期：以上のような分裂過程であるから，多胞子形成その他の不規則が見られる。そ の状態を示せば, 
N. suaveolens $\times N$. plumbaginifolia $\mathrm{F}_{1}$ の四分子期小胞子数

\begin{tabular}{|c|c|c|c|c|c|c|c|c|c|c|c|c|c|c|c|c|c|c|c|}
\hline $\begin{array}{l}\text { 小胞子 } \\
\text { 之微細 } \\
\text { 胞子数 }\end{array}$ & I & $\mathrm{II}+\mathrm{I}$ & $\mathrm{II}_{+}$ & III & $\mathrm{II}+4$ & III & $\mathrm{II}_{+1}$ & IV & $\mathrm{lV}+$ & IV & & $\mathrm{V}+4$ & V & $V+1$ & $V+2$ & VI & $\mathrm{I}_{+1}$ & $\mathrm{~V}+2$ & 合計 \\
\hline 観察数 & 1 & 1 & 6 & 2 & 1 & 2 & 1 & 34 & 52 & 19 & 4 & 1 & 7 & 6 & 1 & 10 & 2 & 1 & 151 \\
\hline
\end{tabular}

*アラピヤ数字は微細胞子数

この外同一小胞子內に小核を 1 箇乃至数䇢含むものがある。

以上のように減数分裂が不規則であるから種子友生じない。

(3) N. suaveolens $\times N$. longiflora の $\mathrm{F}_{1}$

外形は両親の中間である。両親がやや似ているから特徴を取り上げることは困難であるが, 花筒外部の色は longiflora に似てやや紫を帶びている。雜種強勢を示し両親より大きく,多く の枝をだし, 多数の花をつける。開花期も又長い。

減数分裂： 萂の発達が若い蕾では惡い。なすりつけ法で観察するために䓎を圧しつぶした が, 胞原細胞も花粉母細胞も王しだされない。そこでカルノー氏液で固定し永久プレパラート を作つて見た。

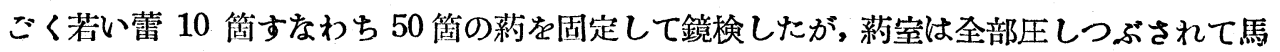
蹄形に彎曲した狭い間隙となりその中に少量の死細胞の遺物が黑くなつているだけであつた。 ただ 10 蕾中 1 箇だけは葋空のやや広いものがあり，死細胞と生細胞が混じていた。もつとも 死細胞の黑くなつた遺物の間に非常に稀れに牛死の丹細胞が存在することが西るが観察には適 当でなかつた。

死細胞と生細胞とを交えたものの観察では, 萂室の內側の絨埸細胞が異常に発達して葋室 が狭ばめられるが，その始まりは何時であるかを決定することはできなかつた。しかし他の蕾 の鿊において, 死細胞の遺骸の間に非常に稀れに胞原細胞の死にかかつたものが見られたから， あるものでは胞原細胞期に既に破壊が初まるとも思われる。なお又この異常に発達した內側の 䄉氈細胞も母細胞の死滅が終局になると，やがて破壊をはじめて黑い遺骸のみを残すようにな り，母細胞の遺骸と混じて圧しひしゃげられ，区别がつかなくなる。

今上の 1 蕾から得た, 生きた花粉母細胞をもつ葯を観察した結果を述べる。

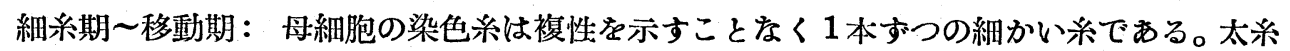
期も同様 1 本であり, 複糸期の染色分体は 1 本すかばらばらに散布しておるが, その若干は 1 简 所に集団している。移動期の染色分体も接着しているものは殆んど見られなかつた。

第一中期：移動期から第一中期に入ると，染色体は一価のままで両阿へ向つて分れるが， 少数のものは赤道附近に集まる。又核膜に沿つて染色体の分散するものもある。赤道附近に集 つた染色体も殆んど一価であり，二価であることは少ない。二価ではないかと思われるものも 紡鍾体の縦軸の方向に列ぶと限らず, それに直角のものが多い, 今中期に拈ける二価染色体の 分布を見る。

$N$. suaveolens $\times N$. longiflora $\mathrm{F}_{1}$ の第一分裂中期染色体構成

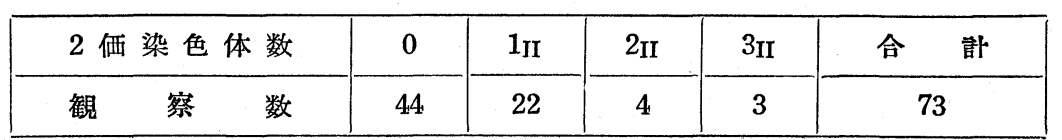




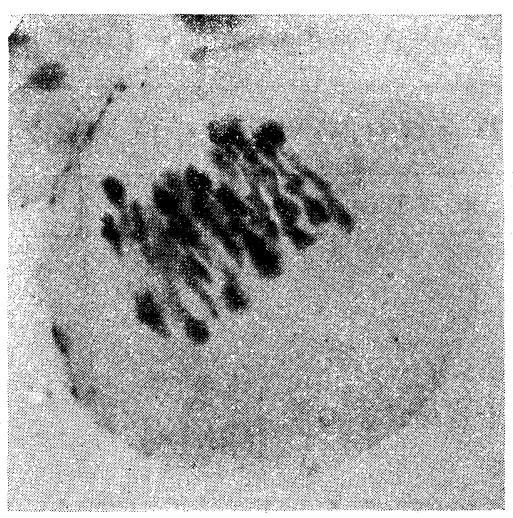

Photo. 1.

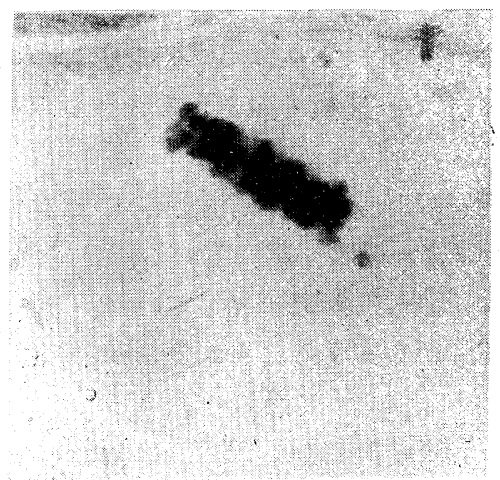

Photo. 3.

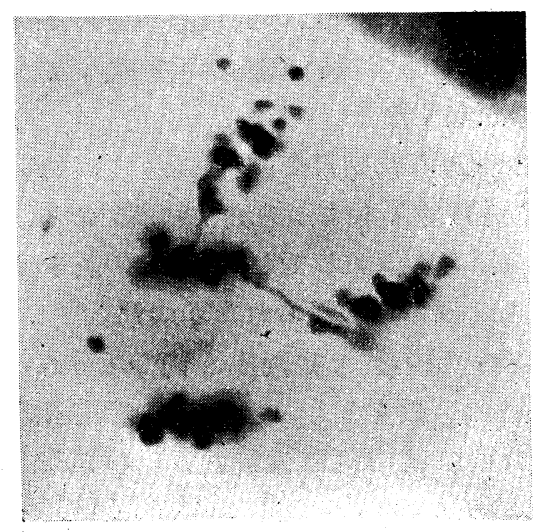

Photo. 5.

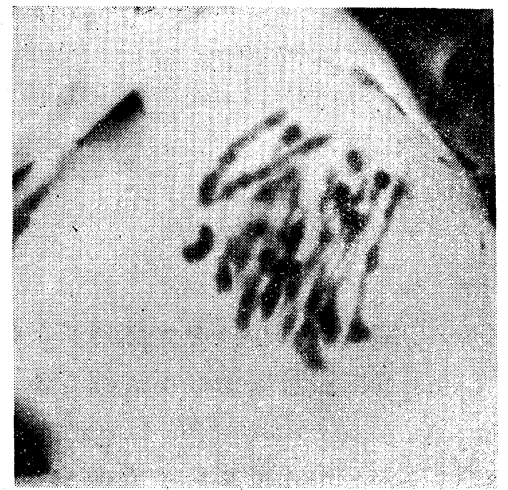

Photo. 2.

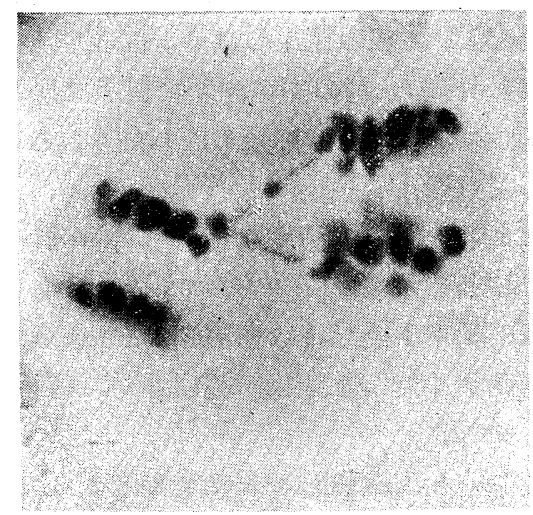

Photo. 4.

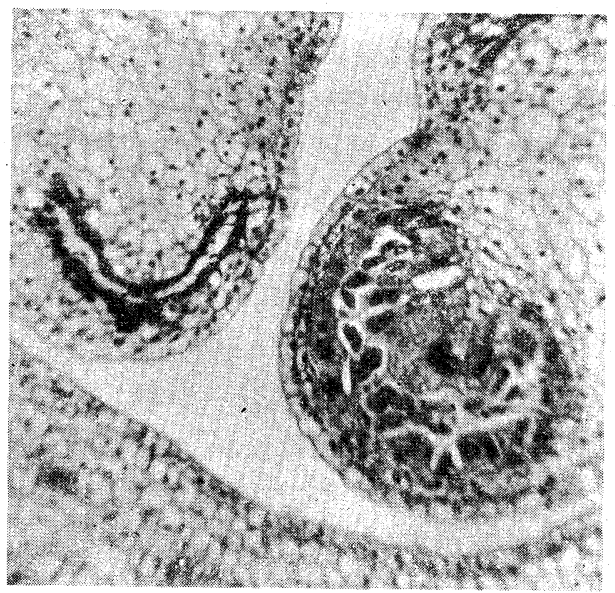

Photo. 6.

Photos. 1-5; chromosome figures in PMC's of the hybrid $N$. suaveolens $\times N$. gossei. Photos. 1-2, chromosome configurations at IM, showing especially various chromosome conjugations. Photo. 3, homeotypic nuclear plate at first division. Photo. 4, splitting chromosome bridge at IIA. Photo. 5, 2 chromosome bridges continuing from IA to IIA.

Photo. 6, pollen sacs of the hybrid $N$. suaveolens $\times N$. longiflora, showing enlarged tapetum cells (right), and degenerated and disintegrated PMC's (left). 
ただしこの二価染色体が眞の漞和性のものか否かは甚だ疑わしい。染色体総数は両親のも のを合せた数で 26 箅であつた。

第二分裂：染色体が縱裂して分配されるが，もちろん第一分裂で主紡鉭体外に放出された 染色体义は染色体群はそれぞれ小さい紡鍾をつくり分裂する。主紡錗体內の両極の染色体数も 種タ様々である。從つて四分子期には多胞子形成が行われて大小種々の小胞子叉は微細胞子が できる。

花粉：開花せるものの䒺は裂開するものと裂開しないものとがある。今裂開している获を 見ると，花粉量は䓕だ少ない。しかも大小様々の少量の花粉粒と多量の花粉の遺骹とがある。 それは花粉の遺骹というょり,むしろ塺埃というべきものである。中には退化した組織形のま

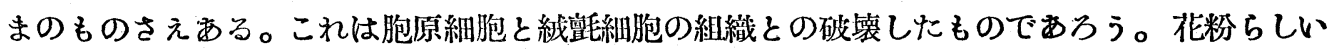

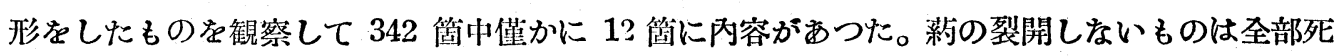
花粉で, 裂開した葯に扔いてさえも生き炕花粉は上のように少ない。もちろん種子はつけない。

\section{論議}

$N$. suaveolens $\times N$. gossei は正逆交配をも容易に種子が得られる。 $N$. suaveolens $\times N$. longiflora そ N. suaveolens $\times N$. plumbaginifolia とは Kostoff (1941-43) のいう通り，辛 じて種子が得られたが，その逆交雜は逐に種子が得られなからた。 N. suaveolens $\times N$. gossei, $N$. suaveolens $\times N$. longiflora, N. suaveolens $\times N$. plumbaginifolia の 3 雜種とも，その外 形は Kostoff の記載の通りであつた。

$N$. suaveolens $(\mathrm{n}=16) \times N$. gossei $(\mathrm{n}=18)$ の $\mathrm{F}_{1}$ の第一分裂では $0 \sim 4$ 簀の一価染色体 の外は二価》至多価染色体で西ることを見た。そして 0 2 筒の一価染色体をもつものが絕体 多数であつたから，16II+2I, 1III+15II+11, 2III+14II の染色体情成のものが多いわけである。 Kostoff (1941-43) も文同じ交雜 $\mathrm{F}_{1}$ で 13 16 箇の二価染色体を見ているが, 多価染色体に はふれていまい。筆者の観察では上の染色体構成の外に,もつと沢山の多価染色体の存在も亦 つた。これは恐らく $N$. gossei $(\mathrm{n}=18)$ と N. suaveolens $(\mathrm{n}=16)$ との関係は, N. gossei が N. suaveolens に比べて, 余分に 2 筒の染色体在もつものではなく,この 2 箅の染色体に含 まれている遺伝子座はもとよりのこと，他の染色体に於ても， suaveolens の染色体との間に幾 つかの転座関係が西ることが考元られる。殊に多数の染色体橋の見られることは,このことを 指示するものとい元よう。この交配 $\mathrm{F}_{1}$ に扔いて第一分裂在省略するものと，第一と第二の分 裂がともに均等分裂であるものとを合せて約 $20 \%$ の多きに達するのは著るしい現象である。

$N$. suaveolens $\times N$. longiflora \& $N$. suaveolens $\times N$. plumbaginifolia $の \mathrm{~F}_{1}$ の花粉度 細胞の研究は Christoff (1929) と Kostoff (1941-43) とによつて発表されている。Christoff はこれ等の交跑の $\mathrm{F}_{1}$ で第一中期に 26 筐の一価染色体を見ているが, Kostoff は N. suaveolens $\times N$. longiflora $て ゙ ~ 0 \sim 3 の, N$. suaveolens $\times N$. plumbaginifolia $て ゙ 0 \sim 4$ の二価染色体 を観察した。筆者の研究が丁度 Kostoff と一致して, 前者で $0 \sim 3$ の, 後者で $0 \sim 4$ の二価染色体 在見たのは, 余りにも珍らしい一致で西る。そして $N$. suaveolens $\times N$. plumbaginifolia では 大多数の母細胞は一価染色体のみのもの (26I) と 1 籄の二価染色体と 24 籄の一価染色体 (1II 2411)との綪成をもつていた。このことから，相当長い部分相同をもつ染色体が両親の間に一組

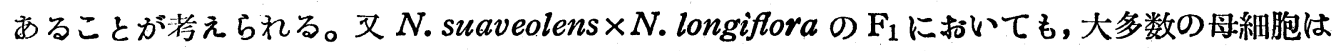
一価染色体のみのもの (26I) と 1 筒の二価染色体と 24 箇の一価染色体 $(1 \mathrm{II}+24 \mathrm{I})$ 構成であつた から，上の交配の場合と同じように染色体部分の相同性が推察される。ただ N. suaveolens $\times$ 
N. longiflora の $\mathrm{F}_{1}$ においては花粉母細胞が死隇することと, 䋐嘎細胞の異常な発達が見られ た点が, N. suaveolens $\times N$. plumbaginifolia の場合と異なる。この原因は上記二組の染色体 間の不和合にもとすくというより，N. suaveolens の細胞質と N. longiflora の染色体との間 の不和合に原因すると考うべきであろう。そして䋐望細胞の異常な発達が，機悈的に母細胞の 破壞を速進するのか, 或はまた母細胞の死滅がホルモン的の作用で䋐壇細胞の異常発達を促が すのかは確定できなかつた。

\section{Summary}

(Reduction divisions in hybrids between $N$. suaveolens and three other species.)

Reciprocal crosses between $N$. suaveolens $(\mathrm{n}=16)$ and four other species, $N$. gossei $(\mathrm{n}=18), N$. alata $(\mathrm{n}=9), N$. longiflora $(\mathrm{n}=10)$ and $N$. plumbaginifolia $(\mathrm{n}=10)$, were carried out. The reciprocal crosses between $N$. suaveolens and $N$. gossei gave always many germinating seeds, while the other six crosses did not produce any seeds, with the exception of $N$. suaveolens $\times N$. longiflora and $N$. suaveolens $\times N$. plumbaginifolia.

In the meiosis of the PMC's of the hybrid N. suaveolens $\times N$. gossei, the chromosome configurations most frequently found were of the following three types, $2 I I+14 I I, 1 I I+15 I I+1 I$ and $16 I I+21$. Besides, several polyvalents were occasionally observed, and many chromosome bridges were seen at first anaphase. This suggests the presence of some inversions or translocations between the chromosomes of $N$. suaveolens and those of $N$. gossei.

The study of meiosis in the PMC's of the two hybrids, N. suaveolens $\times N$. longiflora and $N$. suaveolens $\times N$. plumbaginifolia, agreed very well with Kostoff's observations, the number of bivalents in the former being $0 \sim 3$ and in the latter $0 \sim 4$. Since the chromosome configuration $1 I I+24 \mathrm{I}$ was mostly observed in the above two hybrids, it seems that one pair of chromosomes with long homologous parts in common is present among the chromosomes of $N$. suaveolens and $N$. longiflora or N. plumbaginifolia.

In the hybrid $N$. suaveolens $\times N$. longiflora, cells of the tapetum tissue were strikingly enlarged at an early stage of meiosis, and all PMC's, from unknown causes, almost always degenerated and disintegrated before the end of the reduction division.

(National Institute of Genetics, Misima, Japan.)

\section{引用 文 献}

Christoff, M. (1938) Cytological studies on some species hybrids of Nicotiana. Year book Univ. Sofia, Fac. Agric., $7:$ 289-302. (After Kostoff 1941-43).

Kostoff, D. (1941-43) Cytogenetics of the genus Nicotiana. Karyosystematics, genetics, cytology, cytogenetics, and Phylesis of tobaccos. Sofia.

Takenaka, Y. (1951) Cytogenetic studies of Nicotiana, I. La Kromosomo, 9-10: 384-392.

(1953) Cytogenetic studies of Nicotiana, II. Ibid., 16: 596-601. 